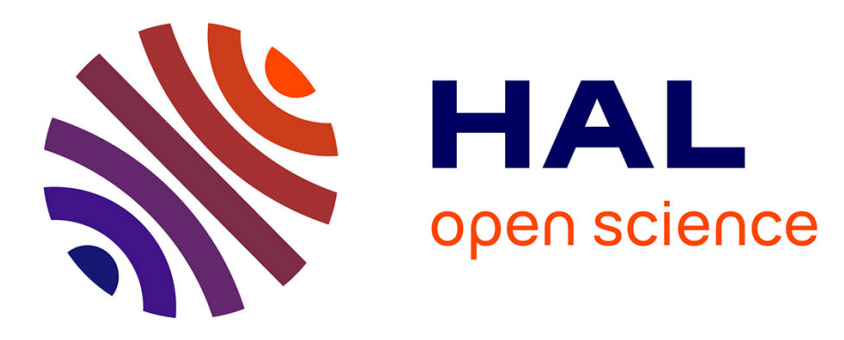

\title{
Description of coordinatively unsaturated sites regeneration over MoS2-based HDS catalysts using 35S experiments combined with computer simulations
}

Franck Dumeignil, Jean-Francois Paul, Edouard Veilly, Eika W. Qian, Atsushi Ishihara, Edmond Payen, Toshiaki Kabe

\section{To cite this version:}

Franck Dumeignil, Jean-Francois Paul, Edouard Veilly, Eika W. Qian, Atsushi Ishihara, et al.. Description of coordinatively unsaturated sites regeneration over MoS2-based HDS catalysts using 35S experiments combined with computer simulations. Applied Catalysis A : General, 2005, 289(1), pp.5158. hal-00098365

\section{HAL Id: hal-00098365 https://hal.science/hal-00098365}

Submitted on 25 Sep 2006

HAL is a multi-disciplinary open access archive for the deposit and dissemination of scientific research documents, whether they are published or not. The documents may come from teaching and research institutions in France or abroad, or from public or private research centers.
L'archive ouverte pluridisciplinaire HAL, est destinée au dépôt et à la diffusion de documents scientifiques de niveau recherche, publiés ou non, émanant des établissements d'enseignement et de recherche français ou étrangers, des laboratoires publics ou privés. 
Description of coordinatively unsaturated sites regeneration over $\mathrm{MoS}_{2}$-based HDS catalysts using ${ }^{35} \mathrm{~S}$ experiments combined with computer simulations

Franck Dumeignil $^{\mathrm{a}}$, Jean-Francois Paul ${ }^{\mathrm{b}}$, Edouard Veilly ${ }^{\mathrm{b}}$, Eika W. Qian ${ }^{\mathrm{a}}$, Atsushi Ishihara $^{a^{*}}$, Edmond Payen $^{b^{*}}$, Toshiaki Kabe ${ }^{\mathrm{a}}$

${ }^{a}$ Department of Chemical Engineering, Tokyo University of Agriculture and Technology, 2-24-16 Nakacho, Koganei, Tokyo 184-8588, Japan

${ }^{b}$ Laboratoire de Catalyse de Lille, Université des Sciences et Technologies de Lille, Bâtiment C3, 59655 Villeneuve d'Ascq CEDEX, France

\footnotetext{
* To whom correspondence should be addressed

E-Mail: atsushii@cc.tuat.ac.jp
}

Edmond.Payen@univ-lille1.fr 


\begin{abstract}
By combining experimental results and computer simulations, we previously showed that the coordinatively unsaturated sites (CUS) formation over $\mathrm{MoS}_{2}$ is most likely to occur on the $\mathrm{MoS}_{2}$ metallic edge through the departure of an $\mathrm{H}_{2} \mathrm{~S}$ molecule. In the present paper, we aimed at examining the $\mathrm{H}_{2} \mathrm{~S}$ departure from $\mathrm{MoS}_{2}$ catalysts promoted with Co and Ni. The $\left[{ }^{35}\right.$ S]DBT HDS experiments results showed that over CoMoS/ $/ \mathrm{Al}_{2} \mathrm{O}_{3}$ and NiMoS/ $\mathrm{Al}_{2} \mathrm{O}_{3}$ catalysts, the activation energy of the $\mathrm{H}_{2} \mathrm{~S}$ release reaction is essentially the same with respective values of $7.4 \mathrm{kcal}_{\mathrm{mol}}{ }^{-1}$ and $7.9 \mathrm{kcal}^{\mathrm{mol}}{ }^{-1}$. Considering the $\mathrm{H}_{2} \mathrm{~S}$ departure activation energy in the case of the non-promoted $\mathrm{MoS}_{2}$ surface $\left(10 \sim 12 \mathrm{kcal}_{\mathrm{mol}}{ }^{-1}\right)$, this result illustrates the synergetic effect between $\mathrm{Mo}$ and $\mathrm{Co}$ or $\mathrm{Ni}$ in terms of CUS regeneration easiness. Further, preliminary computer simulations results showed that for $\mathrm{S}$ atoms bridged between Co atoms, a mechanism implying $\mathrm{H}_{2} \mathrm{~S}$ departure from the metallic edge cannot be reasonably envisaged. Moreover, on the sulfur edge the $\mathrm{H}_{2} \mathrm{~S}$ release activation energy is too high $\left(\sim 13.5 \mathrm{kcal} . \mathrm{mol}^{-1}\right)$ if we consider experimental results on $\mathrm{CoMo} / \mathrm{Al}_{2} \mathrm{O}_{3}$ catalysts but not incompatible with the experimental value obtained over $\mathrm{Co} / \mathrm{Al}_{2} \mathrm{O}_{3}$ catalysts (ca. $10 \mathrm{kcal}^{\mathrm{mol}} \mathrm{m}^{-1}$ ), which suggests that the mechanism on the promoted catalyst differs from that on the un-promoted one.
\end{abstract}

Keywords: HDS, DBT, $\mathrm{MoS}_{2}, \mathrm{CoMoS}, \mathrm{NiMoS}$, activation energy, ${ }^{35} \mathrm{~S}$ tracer experiments, computer simulations, $\mathrm{H}_{2} \mathrm{~S}$ liberation 


\section{Introduction}

Among numerous atmospheric pollution sources, sulfur contained in gasoline is well known for its particularly disastrous effects. Indeed, its presence in the exhaust gas as $\mathrm{SO}_{2}$ is not only responsible for allergies and respiratory disorders such as asthma, but it is also a poison for the catalytic exhaust converters, decreasing progressively their efficiency. Facing this environmental problem, laws limiting the sulfur emissions were early established; they have to be further regularly revised in order to meet more and more exigent environmental protection standards. Accordingly, refineries must periodically reduce the sulfur content of the commercial fuels they provide to the market. For instance, from 1997, the maximum sulfur content in light gas oils was limited to $\sim 500 \mathrm{ppm}$ in most parts of the industrialized world. Further, the $350 \mathrm{ppm}$ actual norm in Europe for light oils will have to be reduced down to $50 \mathrm{ppm}$ before 2005 [1] and furthermore down to 10 ppm before 2009, while Japan plans to decrease the actual value of $50 \mathrm{ppm}$ down to $10 \mathrm{ppm}$ by 2007 ; the USA will impose a reduction of the sulfur level to $15 \mathrm{ppm}$ by 2006 . In order to meet the new criteria, a few technological choices can be considered. Among them, the optimization of the actual hydrodesulfurization (HDS) catalysts seems to provisionally be the most acceptable solution for questions of cost, etc... Conventional HDS catalysts are constituted of alumina-supported $\mathrm{MoS}_{2}$ nanocrystallites, which are promoted with $\mathrm{Ni}$ or Co atoms and optionally further modified with third doping elements, e.g. fluorine [2,3], phosphorus [4-9] or boron [10-14]. In addition, other active phases such as $\mathrm{WS}_{2}$ [15-19], $\mathrm{CrS}_{\mathrm{x}}$ [20-24], noble metals [25-37], as well as other supports than alumina such as $\mathrm{TiO}_{2}$ or mixed oxides [38-48] or carbon [49] and zeolites [50,51] were also investigated, giving a large pallet of active phases with their specific morphology and 
activity. Consequently, more or less elaborated models were respectively developed in order to understand the behavior of each active phase. At first, the elementary $\mathrm{MoS}_{2}$ phase was largely characterized. This phase has a lamellar hexagonal structure [52] and the active sites (anionic sulfur vacancies created by thermal treatment under hydrogen [53]) are believed to be located on the edges of the $\mathrm{MoS}_{2}$ crystallites. Then, the morphology of $\mathrm{MoS}_{2}$ is a very important factor [54,55] for the catalytic performances and it was further characterized by various techniques such as High Resolution Transmission Electron Spectroscopy (HRTEM) [56,57], Extended $X$-ray Absorption Fine Structure (EXAFS), for which it has been recently shown that in-situ measurements are required to obtain reliable information [58-59]. Further, many studies aimed at characterizing the working promoted catalyst (CoMoS) during the HDS process. Among the proposed models, the most accepted by the scientific community is now the Topsøe's model, which was refined by a lot of characterization techniques [60-72].

Besides, ${ }^{35} \mathrm{~S}$ radioactive tracer methods were developed to determine the sulfidation process of HDS catalysts as well as to describe the HDS reaction mechanism over various catalysts under real working conditions [32,34,35,73-80]. On the other hand, with the recent developments of the computer simulations, new insights in the state of the HDS catalysts surface [81-84] as well as an overview of the HDS mechanism over the simulated surfaces were concurrently proposed $[85,86]$. Recently, we proposed for the first time a reliable CUS regeneration mechanism over $\mathrm{MoS}_{2}$ crystallites by combining these two complementary methods [87,88]. In the present paper, after giving a brief description of the results obtained on non-promoted $\mathrm{MoS}_{2}$ catalysts, we will extend investigation to the effect of $\mathrm{Co}$ and $\mathrm{Ni}$ promoted catalyst on the CUS 
regeneration process.

\section{Experimental}

In this part, we will give a brief description of the $\left[{ }^{35}\right.$ S $] D B T$ HDS experiments and of the computer simulations methods, which details are given elsewhere $[87,88]$.

\subsection{The $\left[{ }^{35} \mathrm{~S}\right]$ DBT HDS method}

The catalyst previously packed in the reactor is dried overnight and then sulfided in situ in a $\mathrm{H}_{2} / \mathrm{H}_{2} \mathrm{~S}$ stream typically at $400^{\circ} \mathrm{C}$ for $3 \mathrm{~h}$. The decalin solution of $\left[{ }^{35} \mathrm{~S}\right] \mathrm{DBT}$, which is previously synthesized according to the Gilman and Jacoby method [89], is then supplied by a feed pump. A typical reaction is generally performed under the following conditions: quantity of catalyst $=1 \mathrm{~g}, \mathrm{H}_{2}$ flow $=25 \mathrm{~L} \cdot \mathrm{h}^{-1}$, Weight Hourly Space Velocity $($ WHSV $)=28-56 \mathrm{~h}^{-1}$, reaction pressure $=50 \mathrm{~kg} \cdot \mathrm{cm}^{2}$, concentration of DBT in decalin $=0.5-3 \mathrm{wt} \%$, and reaction temperature $=260-360^{\circ} \mathrm{C}$. The produced $\mathrm{H}_{2} \mathrm{~S}$ is trapped with a commercial scintillation solution (Carbasorb, Packard Co. Ltd.), while the liquid product is collected from a gas-liquid separator. For each run, one liquid product sample and one absorbed $\mathrm{H}_{2} \mathrm{~S}$ solution sample are simultaneously collected every $15 \mathrm{~min}$. The components of the liquid product (unreacted DBT and reaction products) are analyzed by gas chromatography (GC). The radioactivity of the

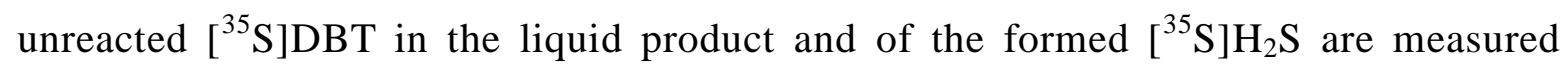
after mixing with a scintillating solution by a liquid scintillation counter (LSC-1000, Aloka, Co. Ltd.) [90-92]. A typical experimental procedure is given in Fig. 1. In the first step, a decalin solution of $\left[{ }^{32} \mathrm{~S}\right] \mathrm{DBT}$ is pumped into the reactor until the DBT conversion becomes constant. Then, the decalin solution of $\left[{ }^{32} \mathrm{~S}\right] \mathrm{DBT}$ is substituted 
with that of $\left[{ }^{35} \mathrm{~S}\right] \mathrm{DBT}$. After replacing the decalin solution of $\left[{ }^{32} \mathrm{~S}\right] \mathrm{DBT}$ with that of $\left[{ }^{35} \mathrm{~S}\right] \mathrm{DBT}$, the radioactivity of the unreacted $\left[{ }^{35} \mathrm{~S}\right] \mathrm{DBT}$ in the liquid product increases, reaching a steady state quasi-immediately. In contrast, the time delay required for the radioactivity due to $\left[{ }^{35} \mathrm{~S}^{-} \mathrm{H}_{2} \mathrm{~S}\right.$ to reach the steady state is about $100 \mathrm{~min}$, indicating that a certain quantity of $\left[{ }^{35} \mathrm{~S}\right] \mathrm{S}$ is progressively incorporated in the active phase (area $\mathrm{A}$ in Fig. 1). Thus, the $\left[{ }^{35} \mathrm{~S}\right] \mathrm{DBT}$ HDS reaction is performed until the amount of $\left[{ }^{35} \mathrm{~S}^{-\mathrm{H}_{2} \mathrm{~S}}\right.$ released becomes constant (achievement of a steady state). Then, the $\left[{ }^{35} \mathrm{~S}\right] \mathrm{DBT}$ solution is replaced with decalin solvent and the radioactivity due to $\left[{ }^{35} \mathrm{~S}^{-\mathrm{H}_{2} \mathrm{~S}}\right.$ decreases immediately. This indicates that the sulfur accumulated on the catalyst cannot be released without supplying sulfur-containing molecules to the catalyst. In the last step of the experimental procedure, decalin is replaced again with the $\left[{ }^{32} \mathrm{~S}\right]$ DBT solution. A peak of $\left[{ }^{35} \mathrm{~S}^{3} \mathrm{H}_{2} \mathrm{~S}\right.$ radioactivity (area $\mathrm{B}$ in Fig. 1) due to the release of $\left[{ }^{35} \mathrm{~S}\right] \mathrm{S}$ previously incorporated in the active phase is then observed.

The reaction conversion can be calculated either from the radioactivity of $\left[{ }^{35} \mathrm{~S}\right] \mathrm{DBT}$ and $\left[{ }^{35} \mathrm{~S}\right] \mathrm{H}_{2} \mathrm{~S}$ at the steady state or from the GC charts. Over classical catalysts, the conversion derived from the GC analysis is in good agreement with the conversion determined from the $\left[{ }^{35} \mathrm{~S}\right]$ radioactivity results.

Further, the results of Fig. 1 can be treated mathematically to access to some reaction parameters. Indeed, the decreasing period observed in Fig. 1 for the $\left[{ }^{35} \mathrm{~S} \mathrm{H}_{2} \mathrm{~S}\right.$ radioactivity can be described by a linear relationship revealed as:

$$
\ln y=\ln z-k t
$$

Where $y$ represents the radioactivity of $\left[{ }^{35} \mathrm{~S}\right] \mathrm{H}_{2} \mathrm{~S}\left(\mathrm{dpm} . \mathrm{min}^{-1}\right), z$ the radioactivity of 
$\left[{ }^{35} \mathrm{~S}_{2} \mathrm{H}_{2} \mathrm{~S}\right.$ at the steady state $\left(\mathrm{dpm} \cdot \mathrm{min}^{-1}\right), k$ the $\left[{ }^{35} \mathrm{~S}\right] \mathrm{H}_{2} \mathrm{~S}$ release rate constant $\left(\mathrm{min}^{-1}\right)$, and $t$ the reaction time $(\mathrm{min})$. The slope of the line obtained by plotting $\ln z$ as a function of $t$ represents therefore the $\left[{ }^{35} \mathrm{~S}^{3} \mathrm{H}_{2} \mathrm{~S}\right.$ release rate constant. Further, when the $\left[{ }^{35} \mathrm{~S}_{2} \mathrm{H}_{2} \mathrm{~S}\right.$ radioactivity is at the steady state, the difference between the total radioactivity introduced on the catalyst by $\left[{ }^{35} \mathrm{~S}\right] \mathrm{DBT}$ HDS and that of the formed $\left[{ }^{35} \mathrm{~S}_{2} \mathrm{H}_{2} \mathrm{~S}\right.$ is equivalent to the total radioactivity remaining on the catalyst. This corresponds to the area (A) and (B) in Fig. 1. These areas are equivalent to the ratio $z / k$ $(\mathrm{dpm})$, which can be calculated from the following integral: $\int_{t=0}^{t=\infty} E q(1)$. Then, $S_{0}$, the amount of labile sulfur incorporated in the catalyst, is $(z / k) /\left(\left[{ }^{35} \mathrm{~S}\right] \mathrm{DBT} /\left[{ }^{32} \mathrm{~S}\right] \mathrm{DBT}\right)[88]$.

It is then also possible to determine the activation energy of the $\mathrm{H}_{2} \mathrm{~S}$ release reaction after determining $k$ at various temperatures, from the slope of the Arrhenius plot of $\ln k$ as a function of $1 / T$.

In addition, we calculated the hydrogenation (HYD) rate constant $k_{\mathrm{HYD}}$, assuming a pseudo first order kinetics treatment, $\mathrm{H}_{2}$ being in great excess. In the present paper, the HYD pathway was classically defined as the reaction of conversion of DBT into cyclochexylbenzene (CHB).

\subsection{Computer simulations}

A detailed experimental procedure for the computer simulations on the $\mathrm{MoS}_{2}$ active phase is given elsewhere [87]. All the results deduced from the calculations have been obtained by using the Vienna Ab-initio Simulation Package (VASP) program [93-97] that performs periodic Density Functional Theory (DFT) calculations including Gradient Corrected Approximation (GGA) [98] correction in order to improve the 
accuracy of the calculation. The transition states were located using the Nudged Elastic Band (NEB) method [99], and characterized by numerical frequency calculations. Considering the number of atoms in a supercell (more than 90 atoms), the overall precision in the calculation of the energies (including the activation energies) was estimated to be around $0.1 \mathrm{eV}$.

\section{Results and discussion}

\subsection{Elementary non-promoted $\mathrm{MoS}_{2}$ phase}

In a previous work $[87,88]$, we determined the CUS formation mechanism over $\mathrm{MoS}_{2} / \mathrm{Al}_{2} \mathrm{O}_{3}$ catalysts by comparing the results of computer simulations with the results of $\left[{ }^{35} \mathrm{~S}_{2} \mathrm{H}_{2} \mathrm{~S}\right.$ experiments. This mechanism, represented in Fig. 2, involves the dissociative adsorption of an $\mathrm{H}_{2}$ molecule on the metallic edge of a $\mathrm{MoS}_{2}$ crystallite surface with further creation of a CUS by release of one $\mathrm{H}_{2} \mathrm{~S}$ molecule in the gas phase. The activation energy of the $\mathrm{H}_{2} \mathrm{~S}$ molecule departure reaction from the surface was calculated at $0.52 \pm 0.1 \mathrm{eV}\left(\sim 12 \pm 2 \mathrm{kcal}^{\mathrm{mol}}{ }^{-1}\right)$ (see the energetic diagram represented in Fig. 3). This value fitted very well with the result of the ${ }^{35} \mathrm{~S}$ radiotracer method, with a value of about $10 \pm 1 \mathrm{kcal}^{\mathrm{mol}}{ }^{-1}$, determined by an Arrhenius plot (see Fig. 4). Moreover, the activation energy of the rate-limiting step (dissociation of the $\mathrm{H}_{2}$ molecule on the $\mathrm{MoS}_{2}$ surface) for the creation of one CUS by the proposed mechanism was $0.97 \mathrm{eV}\left(23 \mathrm{kcal}^{\mathrm{mol}} \mathrm{l}^{-1}\right)$, which was also in very good agreement with the experimental activation energy of the DBT HDS reaction (about $20 \sim 22 \mathrm{kcal}^{\mathrm{mol}} \mathrm{m}^{-1}$ ). This suggested that the DBT HDS reaction rate is intrinsically limited by the $\mathrm{H}_{2}$ dissociation rate on the $\mathrm{MoS}_{2}$ phase, as the activation energy of the CUS creation or regeneration reaction over $\mathrm{MoS}_{2}$ is almost the same as the energy 
activation of DBT HDS reaction observed over $\mathrm{MoS}_{2}$. This is different from the results of 4,6-DMDBT HDS reaction, for which the activation energy is higher $\left(\sim 32 \mathrm{kcal}^{\mathrm{mol}}{ }^{-1}\right)$, suggesting that the limiting factor might not be the regeneration of CUS over the $\mathrm{MoS}_{2}$ surface [88].

Further, in the case of severe experimental conditions, a second mechanism involving a CUS creation on the sulfur edge by two successive steps (creation of an isomer edge with two $\mathrm{S}-\mathrm{H}$ groups and then departure of an $\mathrm{H}_{2} \mathrm{~S}$ molecule) can also reasonably be considered. For this mechanism, the activation energy for the $\mathrm{H}_{2} \mathrm{~S}$ release reaction was calculated at $1.42 \mathrm{eV}\left(33 \mathrm{kcal}_{\mathrm{mol}} \mathrm{m}^{-1}\right)$, while the activation energy of the rate-limiting step was of $0.30 \mathrm{eV}\left(7 \mathrm{kcal} . \mathrm{mol}^{-1}\right)$ [87].

\subsection{Promoted $\mathrm{MoS}_{2}$ phase}

\subsubsection{CoMoS phase}

\section{a) Experimental results}

Figure 5 represents $S_{0}$, the quantity of labile sulfur atoms per gram of catalyst, and $k_{\mathrm{RE}}$, the $\mathrm{H}_{2} \mathrm{~S}$ release reaction rate constant as a function of the Co / Mo ratio, both obtained at $260^{\circ} \mathrm{C}$ for a series $\mathrm{CoMo} / \mathrm{Al}_{2} \mathrm{O}_{3}$ catalysts loaded with $16 \mathrm{wt} \%$ Mo $[75,77]$. While $S_{0}$ increased with the Co/Mo ratio up to Co / Mo $=0.4 \sim 0.6, k_{\mathrm{RE}}$ of the promoted catalysts exhibited a constant value, irrespective of the Co / Mo ratio $\left(\sim 6.2 \times 10^{-4} \cdot \mathrm{s}^{-1}\right)$. Further, Fig. 6 shows the promotion effect of Co on the HYD $(=$ formation of CHB) and the global HDS activity of $\mathrm{MoS}_{2}$ based catalysts. The promotion effect is represented by $k / k_{0}$, where $k$ represents the HYD (= rate constant of the HYD route) or the HDS reaction rate constant for a given Co / Mo ratio and $k_{0}$ represents this rate constant for the corresponding non-promoted catalyst 
$\left(16 \mathrm{wt} \% \mathrm{Mo} / \mathrm{Al}_{2} \mathrm{O}_{3}\right)$. While the global HDS promotion factor was of about 25 times in the best case, the HYD reaction pathway promotion one was more moderate and did not exceed 10. In both cases a maximum was observed near Co / Mo $=0.6$, which corresponds also to a maximum in $S_{0}$ (Fig. 5). This result suggested that the promoting effect of Co is rather due to an increase in the number of active sites with an enhanced activity (better sulfur mobility).

Further, we calculated the $\mathrm{H}_{2} \mathrm{~S}$ release activation energy from an Arrhenius plot (Fig. 7). As a remark, we did not take into account the point for $\mathrm{Co} / \mathrm{Mo}=1$, as it corresponds to a catalyst with decreased performances (Fig. 5). We found a value of about $7.4 \mathrm{kcal} . \mathrm{mol}^{-1}$, which is lower than that observed on non-promoted $\mathrm{Mo} / \mathrm{Al}_{2} \mathrm{O}_{3}$ catalysts $\left(\sim 10 \mathrm{kcal}^{\mathrm{mol}}{ }^{-1}[74,88]\right)$. In contrast, the activation energy of the HDS reaction was about $23 \pm 1 \mathrm{kcal}^{\mathrm{mol}}{ }^{-1}$ whatever the Co loading [75,77], which is almost equivalent to the value observed on non-promoted catalysts (about $20 \sim 22 \mathrm{kcal} . \mathrm{mol}^{-1}$ ). This suggests that the addition of cobalt to the $\mathrm{MoS}_{2}$ active phase might essentially not modify the activation energies of the reaction steps that are directly involved in the C-S bond breaking, but that it has an effect on the sulfur mobility.

The $\mathrm{H}_{2} \mathrm{~S}$ release activation energy for $\mathrm{Co}_{9} \mathrm{~S}_{8}$ (i.e. for $\mathrm{Co} / \mathrm{Al}_{2} \mathrm{O}_{3}$ catalysts), deduced from the experimental results is $\sim 10.0 \mathrm{kcal}_{\mathrm{mol}}{ }^{-1}$ (results for $3.8 \mathrm{wt} \%$ Co on alumina in Fig. 7). This value is calculated from a slope defined by only two points but this is supposedly sufficient considering the accuracy of our method. Indeed, for example in the same figure, the $\mathrm{R}^{2}$ of the linear regression for the non-doped catalyst is as high as 0.9999 (in contrast, when varying the promotor to molybdenum ratio or the molybdenum content, it is true that some fluctuations can be observed). This value of 
$10.0 \mathrm{kcal} . \mathrm{mol}^{-1}$ is equivalent to the experimental value obtained over $\mathrm{MoS}_{2}$. In this case, the activation energy of the DBT HDS reaction is of $c a .20 \mathrm{kcal}^{\mathrm{mol}}{ }^{-1}$, which is also very close to the value obtained over $\operatorname{MoS}_{2}\left(\right.$ about $20 \sim 22 \mathrm{kcal} . \mathrm{mol}^{-1}$ ).

\section{b) Computer simulations results}

This part takes into account the results of computer simulation studies, which are detailed elsewhere $[87,100]$. First, as the results over $\mathrm{MoS}_{2}$ showed that the CUS formation mechanism occurs on the $\mathrm{MoS}_{2}$ metallic edge, we decided to simulate a new metallic edge in which all the Mo atoms were replaced with Co atoms. The mechanism of sulfur departure was simulated starting from a surface containing a sulfur atom in bridging position between two Co atoms, which is the most stable position for a $S$ atom leaved by a DBT molecule on the thermodynacally stable edge. The energetic diagram obtained for the departure of a $\mathrm{H}_{2} \mathrm{~S}$ molecule from the $\mathrm{CoS}$ metallic edge is presented in Fig. 8. This figure shows that there is almost no energy variation upon this sulfur elimination and that the corresponding activation energy is of $1.1 \mathrm{eV}$ $\left(\sim 26 \mathrm{kcal} . \mathrm{mol}^{-1}\right)$. This result suggests that the metallic edge might not be active. Anyway, recent results suggesting that the Co is rather located on the sulfur edge $[101,102]$, a $\mathrm{MoS}_{2}$ sulfur edge on which the Mo atoms were replaced by Co atoms was simulated. The energetic diagram obtained for the departure of a $\mathrm{H}_{2} \mathrm{~S}$ molecule from this sulfur edge is represented in Fig. 9. It shows that the activation energy for the departure of the $\mathrm{H}_{2} \mathrm{~S}$ molecule is of $0.57 \mathrm{eV}\left(\mathrm{ca} .13 .5 \mathrm{kcal}^{\mathrm{mol}}{ }^{-1}\right)$. This value, that is similar to that observed over $\mathrm{Co} / \mathrm{Al}_{2} \mathrm{O}_{3}\left(\sim 10 \mathrm{kcal} \mathrm{mol}^{-1}\right)$, is higher than that obtained over $\mathrm{CoMo} / \mathrm{Al}_{2} \mathrm{O}_{3}\left(\sim 7.4 \mathrm{kcal} . \mathrm{mol}^{-1}\right)$. This suggests that the mechanism and/or the surface state do not correspond to the simulated one(s). Furthermore, in the case of the 
sulfur edge, the $\mathrm{H}_{2} \mathrm{~S}$ release reaction itself appears as the reaction-limiting step as it corresponds to the highest activation energy among all the intermediate steps. In contrast, the activation energy for the DBT HDS reaction over $\mathrm{Co} / \mathrm{Al}_{2} \mathrm{O}_{3}$ and $\mathrm{CoMo} / \mathrm{Al}_{2} \mathrm{O}_{3}$ are both higher than that of this limiting step with respective values of $23 \mathrm{kcal}^{\mathrm{mol}} \mathrm{l}^{-1}$ and $20 \mathrm{kcal}^{\mathrm{mol}}{ }^{-1}$. Thus, these results suggest that the simulated mechanism of $\mathrm{H}_{2} \mathrm{~S}$ release from the sulfur edge could be representative of what occurs over $\mathrm{Co}_{9} \mathrm{~S}_{8}$. If this is effectively the case, that would mean that the DBT HDS reaction limiting step over $\mathrm{Co}_{9} \mathrm{~S}_{8}$ is neither the $\mathrm{H}_{2}$ molecule dissociation contrary to the case of $\mathrm{MoS}_{2}[87,88]$, nor the $\mathrm{H}_{2} \mathrm{~S}$ departure because the activation energy is too low compared to the activation energy of the DBT HDS reaction. The limiting step might therefore be intrinsic to the DBT desulfurization reaction itself. In contrast, in the case of $\mathrm{MoS}_{2}$, the calculated $\mathrm{H}_{2}$ dissociation energy, which is the limiting step of the $\mathrm{H}_{2} \mathrm{~S}$ departure reaction, was very close to the activation energy of the DBT HDS reaction, with respective values of $\sim 23 \mathrm{kcal} . \mathrm{mol}^{-1}$ and $20 \sim 22 \mathrm{kcal} . \mathrm{mol}^{-1}$.

This work shows that the results obtained over the $\mathrm{MoS}_{2}$ phase cannot be transferred directly to the CoMoS phase to explain the promoting effect. Further simulations are now under progress and first results suggest that the surface isomerisation pathway previously evocated for the $\mathrm{H}_{2} \mathrm{~S}$ molecule release in 2 steps in the non promoted catalyst $[87,88]$ might be profitably investigated for determining the CUS creation mechanism over CoMoS.

\subsubsection{NiMoS phase}

In contrast to what it was observed over the CoMo catalysts, $k_{\mathrm{RE}}$ of the NiMo catalysts exhibits a maximum near $\mathrm{Ni} / \mathrm{Mo}=0.4$ (Fig. 5), which approximately 
corresponds to the maximum observed in HYD or HDS (Fig. 6). Besides, while the HDS reaction promotion extent over the NiMo catalysts is roughly the same as that observed over the CoMo catalysts, the HYD reaction promotion (HYD pathway) extent over the NiMo catalysts is about 10 times higher than that observed over the CoMo catalysts (with a maximum of $\sim 80$ vs. $\sim 8$; see Fig. 6), illustrating the excellent HYD properties of Ni-based catalysts. In addition, contrarily to the CoMo catalysts for which $S_{0}$ reached a maximum near the maximum of activity, i.e. near $\mathrm{Co} / \mathrm{Mo}=0.5$, over the NiMo catalysts, $S_{0}$ increased up to Ni/Mo $=1$, with nevertheless the tendency to reach a plateau for Ni/Mo > 0.6 (Fig. 6).

Then, like in the case of the CoMo catalysts, we plotted $\ln k_{\mathrm{RE}}$ as a function of $1000 / T$, in order to determine the activation energy of the $\mathrm{H}_{2} \mathrm{~S}$ release reaction over the NiMo catalysts (Fig.10). As a result, we found an activation energy very close to that observed over the CoMo catalysts. Indeed, for the NiMo catalysts the value is $\sim 7.9 \mathrm{kcal} . \mathrm{mol}^{-1}$, while it is $\sim 7.4 \mathrm{kcal}^{\mathrm{mol}}{ }^{-1}$ for the CoMo catalysts. Furthermore, the DBT HDS activation energy was almost identical to that observed over the CoMo catalysts, with a value of $\sim 20 \pm 1 \mathrm{kcal}^{\mathrm{mol}}{ }^{-1}$. These results suggest that despite the differences observed in the behavior of $k_{\mathrm{RE}}$ and $S_{0}$ as well as in the HYD properties of the NiMo and the CoMo catalysts, the promotion of the DBT HDS properties of these promoted catalysts might be essentially of the same type on both the $\mathrm{Co}$ or $\mathrm{Ni}$ promoted catalysts and assigned to a larger CUS regeneration turn-over frequency (TOF). 


\section{Conclusions}

The $\left[{ }^{35} \mathrm{~S}\right] \mathrm{DBT}$ HDS experiments allowed to determine the activation energy of the $\mathrm{H}_{2} \mathrm{~S}$ release reaction from promoted and non-promoted $\mathrm{MoS}_{2}$. On NiMo/Al $\mathrm{Al}_{2} \mathrm{O}_{3}$ catalysts this energy was of $7.9 \mathrm{kcal}_{\mathrm{mol}} \mathrm{m}^{-1}$, which was almost the same value as that obtained on $\mathrm{CoMo} / \mathrm{Al}_{2} \mathrm{O}_{3}$ catalysts $\left(7.4 \mathrm{kcal} . \mathrm{mol}^{-1}\right)$. In contrast, over non-promoted $\mathrm{Mo} / \mathrm{Al}_{2} \mathrm{O}_{3}$ catalysts this energy was of about $10 \mathrm{kcal} \cdot \mathrm{mol}^{-1}$. This illustrates the fact that the synergetic effect between Mo and $\mathrm{Ni}$ or Co is linked, at least in part, to a better mobility of the sulfur over the promoted catalysts under the experimental conditions.

An excellent correlation between the experiments and computer simulations allowed us to propose in a previous paper an $\mathrm{H}_{2} \mathrm{~S}$ liberation mechanism over $\mathrm{MoS}_{2}$, which takes place on the metallic edge. The experimental value of the activation en ergy of the $\mathrm{H}_{2} \mathrm{~S}$ release reaction fitted very well with the simulated one with respective values of $10 \pm 1 \mathrm{kcal}^{\mathrm{mol}} \mathrm{m}^{-1}$ and $12 \pm 2 \mathrm{kcal} \cdot \mathrm{mol}^{-1}$. In contrast, preliminary calculations on cells where the Mo atoms of the edges were replaced with Co atoms showed that the possibility of a $\mathrm{H}_{2} \mathrm{~S}$ departure mechanism from the metallic edge could be eliminated. Further, results of simulation on the sulfur edge gave an activation energy for the $\mathrm{H}_{2} \mathrm{~S}$ release reaction of $c a .13 .5 \mathrm{kcal}_{\mathrm{mol}}{ }^{-1}$, which does not fit with the experiments over $\mathrm{CoMo} / \mathrm{Al}_{2} \mathrm{O}_{3}$ catalysts $\left(7.4 \mathrm{kcal} . \mathrm{mol}^{-1}\right)$ but might correspond rather well to the case of $\mathrm{Co} / \mathrm{Al}_{2} \mathrm{O}_{3}$ catalysts (experimental value of $c a .10 \mathrm{kcal} \cdot \mathrm{mol}^{-1}$ ).

Then, in order to reliably describe the CUS creation mechanism over promoted $\mathrm{MoS}_{2}$ catalysts, we are examining the possibility of surface isomerizations. Moreover, we will also perform simulations implying the departure of sulfur atoms in bridging position between a Co atom and a Mo atom, as the observed synergetic effect between Co and Mo in the HDS reaction might originate from the special mobility of sulfur 
atoms in such a configuration [75]. Then, computer simulations on the NiMoS phase will be performed by analogy to the simulations performed on the CoMoS phase, when the mechanism over CoMoS will have been unambiguously elucidated.

\section{Acknowledgements}

Authors would like to thank the Japan Society for the Promotion of Science (JSPS) for its financial contribution. Further, a part of this work was performed within the 'Groupement de recherche européen Dynamique moléculaire appliquée à la catalyse', a joint project of the 'Centre National de la Recherche Scientifique' (CNRS), the 'Institut Français du Pétrole' (IFP), 'Universität Wien', ‘Totalfinaelf', and 'Technische Universiteit Eindhoven'. The authors want to thank IDRIS/CNRS and 'le centre de calcul de l'Université de Lille 1' (founded partially by Feder) for the CPU time allocation. 


\section{References}

[1] European Directive 98/70/CE, 1998.

[2] G. Muralidhar, F.E. Massoth, J. Shabtai, J. Catal. 85 (1984) 44.

[3] C. Kwak, J.J. Lee, J.S. Bae, K. Choi, S.H. Moon, Appl. Catal. A :General 200 (2000) 233.

[4] R. Iwamoto, J. Grimblot, Adv. Catal. 44 (1999) 417.

[5] J.L.G. Fierro, A. Lopez Agudo, N. Esquivel, R. Lopez Cordero, Appl. Catal. 48 (1989) 353.

[6] P.J. Mangnus, J.A.R. van Veen, S. Eijbouts, V.H.J. de Beer, J.A. Moulijn, Appl. Catal. 61 (1990) 99.

[7] J.M. Lewis, R.A. Kydd, R.M. Boorman, P.H. van Rhyn, Appl. Catal. A 84 (1992) 103.

[8] M. Jian, R. Prins, Catal. Lett. 35 (1995) 193.

[9] J. Quartararo, J.P. Amoureux, J. Grimblot, J. of Mol. Cat. A: Chemical 162(1-2) (2000) 353.

[10] J. Ramírez, P. Castillo, L. Cedeño, R. Cuevas, M. Castillo, J. M. Palacios, A. López-Agudo, Appl. Catal. A: General 132 (1995) 317.

[11] F. M. Bautista, J. M. Campelo, A. Garcia, D. Luna, J. M. Marinas, M. C. Moreno, A. A. Romero, Appl. Catal. A: General 170 (1998) 159.

[12] C. Li, Y.-W. Chen, S.-J. Yang, J.-C. Wu, Ind. Eng. Chem. Res. 32 (1993) 1573.

[13] J. L. Dubois, S. Fujieda, Catal. Tod. 29 (1996) 191.

[14] G. Muralidhar, F. E. Massoth, J. Shabtai, J. Catal. 85 (1984) 44. 
[15] M. Breysse, J. Bachelier, J.P. Bonnelle, M. Cattenot, D. Cornet, T. Decamp, J.C.

Duchet, R. Durand, P. Engelhard, R. Frety, C. Gachet, P. Geneste, J. Grimblot, C.

Gueguen, S. Kasztelan, M. Lacroix, J.C. Lavalley, C. Leclercq, C. Moreau, L. de

Mourgues, J.L. Olive, E. Payen, J.L. Portefaix, H. Toulhoat, M. Vrinat, Bull. Soc.

Chim. Bel. 96 (1987), 829.

[16] M. Breysse, M. Cattenot, T. Decamp, R. Frety, C. Gachet, M. Lacroix, C. Leclerq,

L. de Mourques, J.L. Portefaix, M. Vrinat, M. Houari, J. Grimblot, S. Kasztelan, J.P.

Bonnelle, S. Housni, J. Bachelier, J.C. Duchet, Catal. Tod. 4 (1988) 39.

[17] J. Vakros, C. Kordulis, Appl. Catal. A: General 217 (1-2) (2001) 287.

[18] M. Suvanto, J. Raty, T. A. Pakkanen, Appl. Catal. A: General 181(1) (1999) 189.

[19] M.J. Vissenberg, Y. Van der Meer, E.J.M. Hensen, V.H.J. de Beer, A.M. van der

Kraan, R.A. van Santen, J.A.R. van Veen, J. Catal. 198 (2001) 151.

[20] F. Dumeignil, H. Amano, D. Wang, E.W. Qian, A. Ishihara, T. Kabe, Appl. Catal.

A: General 249(2) (2003) 255.

[21] T.A. Pecoraro, R.R. Chianelli, J. Catal. 67 (1981) 430.

[22] M. Lacroix, N. Bourtafa, C. Guillard, M. Vrinat, M. Breysse, J. Catal. 120 (1989)

473.

[23] M.J. Ledoux, O. Michaux, G. Agostini, P. Panissod, J. Catal.102 (1986) 275.

[24] W. Qian, T. Kawano, A. Funato, A. Ishihara, T. Kabe, Phys.Chem. Chem. Phys. 3 
(2001) 261.

[25] M. Vrinat, M. Lacroix, M. Breysse, L. Mosoni, M. Roubin, Catal. Lett. 3 (1989) 405.

[26] A.P. Raje, S.-J. Liaw, R. Srinivasan, B.H. Davis, Appl. Catal. 150 (1997) 319.

[27] T. A. Pecoraro, R.R. Chianelli, J. Catal. 67 (1981) 430.

[28] M. Lacroix, N. Boutarfa, C. Guillard, M. Vrinat, M. Breysse, J. Catal. 120 (1989) 473.

[29] J. Shabtai, N.K. Nag, F.E. Massoth, J. Catal. 104 (1987) 413.

[30] J.A. De Los Reyes, M. Vrinat, C. Geantet, M. Breysse, Catal. Today 10 (1991) 645.

[31] K. Lu, Y.J. Kuo, B.J. Tatarchuk, J. Catal. 116 (1989) 373.

[32] A. Ishihara, J. Lee, F. Dumeignil, R. Higashi, A. Wang, E.W. Qian, T. Kabe, J. Catal. 217 (2003) 59.

[33] A. Ishihara, J. Lee, F. Dumeignil, E.W. Qian, T. Kabe, J. Catal. 224(2) (2004) 243.

[34] J. Lee, A. Ishihara, F. Dumeignil, E.W. Qian, T. Kabe, J. Mol. Cat. 213(2) (2004) 207.

[35] J. Lee, A. Ishihara, F. Dumeignil, K. Miyazaki, Y. Oomori, E.W. Qian, T. Kabe, J. Mol. Cat. 209(1-2) (2004) 155.

[36] A.M. Venezia, V. La Parola, G. Deganello, B. Pawelec, J.L.G. Fierro, J. Catal. 215 (2003) 317.

[37] Y. Ogawa, M. Toba, Y. Yoshimura, Appl. Catal. A: General 246(2) (2003) 213.

[38] T. Klimowa, D.S. Casados, J. Ramírez, Catal. Tod. 43(1-2) (1998) 135.

[39] V.L. Barrio, P.L. Arias, J.F. Cambra, M.B. Güemez, B. Pawelec, J.L.G. Fierro, Fuel 82(5) (2003) 501.

[40] J. Ramirez, S. Fuentes, G. Diaz, M. Vrinat, M. Breysse, M. Lacroix, Appl. Catal. 52 
(1989) 211.

[41] Y. Okamoto, A. Maezawa, T. Imanaka, J. Catal. 120 (1989) 29.

[42] J. Ramirez, L. Ruiz-Ramirez, L. Cedeno, V. Harle, M. Vrinat, M. Breysse, Appl. Catal. A 93 (1993) 163.

[43] E. Lecrenay, K. Sakanishi, T. Nagamatsu, I. Mochida, T.Suzuka, Appl. Catal. B 18 (1998) 325.

[44] S. Yoshinaka, K. Segawa, Catal. Tod. 45 (1998) 293.

[45] Z. B. Wei, C. D. Wei, Q. Xin, Acta Physico-chemica Sinica 10 (1994) 402.

[46] C. Pophal, F. Kameda, K. Hoshino, S. Yoshinaka, K. Segawa, Catal. Today 39(1-2) (1997) 21.

[47] D.H. Wang, E.W. Qian, A. Ishihara, T. Kabe, J. Catal. 209 (2002) 266.

[48] A. Ishihara, F. Dumeignil, D. Wang, X. Li, H. Arakawa, E.W. Qian, S. Inoue, A. Muto, T. Kabe, J. Jpn. Petrol. Inst. 48(1) (2005) 37.

[49] B. Pawelec, R. Mariscal, J.L.G. Fierro, A. Greenwood, P.T. Vasudevan, Appl. Catal. A: General 206(2) (2001) 295.

[50] M. Sugioka, F. Sado, T. Kurosaka, X. Wang, Catal. Today 45 (1998) 327.

[51] G. Pérot, Catal. Today 86 (2003) 111.

[52] G. A. Tsigdinos, Aspects of Molybdenum Chemistry, Topics in Current Chemistry 75, Springer Verlag, Berlin, 1978, p.65

[53] A. Wanbeke, L. Jalowiecki, S. Kasztelan, J. Grimblot, J. - P. Bonnelle, J. Catal. 109 (1988) 320.

[54] S. Kasztelan, H. Toulhoat, J. Grimblot, J. - P. Bonnelle, Appl. Catal. 13 (1994) 127.

[55] S. Kasztelan, H. Toulhoat, J. Grimblot, J. - P. Bonnelle, C. R. Acad. Sci. 299 (II) (1984) 289. 
[56] C. Mauchaussé, PhD thesis, Lyon, 1988.

[57] S. Srinivasan, A. K. Datye, C. H. F. Peden, J. Catal. 137 (1992) 513.

[58] T. Shido, R. Prins, J. Phys. Chem B102 (1998) 8426.

[59] G. Plazenet, S. Cristol, J.F. Paul, E. Payen, J. Lynch, Phys. Chem. Chem. Phys. 3 (2001) 246.

[60] R. Candia, O. Sorensen, J. Villadsen, N.Y. Topsøe, B.S. Clausen, H. Topsøe, Bull. Soc. Chim. Belg. 93(8-9) (1984) 763.

[61] C. Wivel, B. S. Clausen, R. Candia, S. Morup, H. Topsøe, J. Catal. 87 (1984) 497.

[62] R. Candia, B. S. Clausen, H. Topsøe, J. Catal. 77 (1982) 564.

[63] I. Alstrup, I. Chorkendorff, R. Candia, B. S. Clausen, H. Topsøe, J. Catal. 77 (1982) 397.

[64] N. Y. Topose, H. Topsøe, J. Catal. 84 (1983) 386.

[65] H. Topsøe, B. S. Clausen, Appl. Catal. 25 (1986) 273.

[66] B. Scheffer, E. M. van Oers, P. Arnoldy, V. H. J. de Beer, J. A. Moulijn, Appl. Catal. 25 (1986) 303.

[67] J. A. Rob van Veen, E. Gerkema, A. M. Vans der Kraan, A. Knoester, J. Chem. Soc. Chem. Commun. (1987) 1684.

[68] M. W. J. Crajé, V. H. J. de Beer, J. A. R. van Veen, A. M. van der Kraan, J. Catal. $143(1993) 601$.

[69] J. L. Brito, J. Laine, J. Catal. 139 (1993) 540.

[70] S. M. A. M. Bouwens, J. A. R. van Veen, D. C. Koningsberger, V. H. J. de Beer, R. Prins, J. Phys. Chem. 95 (1991) 123.

[71] S. P. A. Louwers, R. Prins, J. Catal. 139 (1993) 525. 
[72] S. Houssenbay, S. Kasztelan, H. Toulhoat, J. - P. Bonnelle, J. Grimblot, J. Phys. Chem. 93 (1989) 7176.

[73] W. Qian, A. Ishihara, S. Ogawa, T. Kabe, J. Phys. Chem. 98 (1994) 907.

[74] W. Qian, Q. Zang, Y. Okoshi, A. Ishihara, T. Kabe, J. Soc. Faraday Trans. 93(9) (1997) 1821.

[75] W. Qian, A. Ishihara, Y. Okoshi, W. Nakakami, M. Godo, T. Kabe, J. Soc.

Faraday Trans. 93(24) (1997) 4395.

[76] T. Kabe, W. Qian, A. Ishihara, J. Phys. Chem. 98 (1993) 912.

[77] T. Kabe, A. Ishihara, W. Qian, M. Godo, Catal. Today 45 (1998) 285.

[78] V. M. Kogan, N. N. Rozhdestvenskaya, I. K. Korshevets, Appl. Catal. A: General 234(1-2) (2002) 207.

[79] V. M. Kogan, Appl. Catal. A: General 237(1-2) (2002) 161.

[80] V. M. Kogan, N. N. Rozhdestvenskaya, I. K. Korshevets, Appl. Catal. A: General 251(1) (2003) 187.

[81] S. Cristol, J. F. Paul, E. Payen, D. Bougeard, S. Clémendot, F. Hutschka, J. Phys.

Chem. B 104 (2000) 11220.

[82] P. Raybaud, J. Hafner, G. Kresse, S. Kasztelan, H. Toulhoat, J. Catal. 189 (2000) 129. 
[83] S. Cristol, J. F. Paul, E. Payen, D. Bougeard, S. Clémendot, F. Hutschka, J. Phys.

Chem. B 106 (2002) 5659.

[84] H. Schweiger, P. Raybaud, G. Kresse. H. Toulhoat, J. Catal. 207 (2002) 76.

[85] P. Raybaud, PhD Thesis, Université Pierre et Marie Curie (Paris IV), 1998.

[86] S. Cristol, PhD Thesis, Université de Provence (Aix-Marseilles I), 2000.

[87] J.-F. Paul, E. Payen, J. Phys. Chem. B 107 (2003) 4057.

[88] F. Dumeignil, J.-F. Paul, W.H. Qian, A. Ishihara, E. Payen, T. Kabe, Research on

Chemical Intermediates 29(6) (2003) 589.

[89] H. Gilman, L. Jacoby, J. Org. Chem. 4 (1939) 108.

[90] Y. Kobayashi, D. V. Maudsley, Biological Applications of Liquid Scintillation

Counting, Academic Press, New York, 1974.

[91] D. L. Horrocks, Applications Liquid Scintillation Counting, Academic Press, New York, 1974.

[92] M. Crook in P. Johnson (Ed.), Liquid Scintillation Counting Vol.4, Heyden, London, 1977.

[93] G. Kresse, J. Hafner, Phys. Rev. B47 (1993) 558.

[94] G. Kresse, J. Hafner, Phys. Rev. B49 (1994) 14251.

[95] G. Kresse, J. Furthmüller, Phys. Rev. B54 (1996) 11169. 
[96] G. Kresse, J. Furthmüller, J. Comp. Mater. Sci. 6 (1996) 15.

[97] http://cms.mpi.univie.ac.at/vasp/.

[98] J. P. Perdew, Y. Wang, Phys Rev. B 45 (1992) 13224.

[99] G. Henkelman, B. P. Uberuaga, H. Jonsson, J. Chem. Phys. 113 (2000) 9901.

[100] E. Veilly, PhD Thesis, Université des Sciences et Technologies de Lille, 2003.

[101] H. Schweiger, P. Raybaud, H. Toulhoat, J. Catal. 212(1) 2002, 33.

[102] M. Suna, J. Adjayeb, A. E. Nelson, Appl. Catal. A: General 263(2) 2004, 131.

[103] W. Qian, Y. Hachiya, D. Wang, K. Hirabayashi, A. Ishihara, T. Kabe, H. Ozaki, M. Adachi, Appl. Catal. A: General 227 (2002) 18.

[104] T. Kabe, W. Qian, S. Ogawa, A. Ishihara, J. Catal. 143 (1993) 239. 


\section{Figures captions}

Fig. 1 Operation procedure for HDS of $\left[{ }^{35}\right] \mathrm{S}$ DBT: a typical result. $(\bullet)$ radioactivity due to $\left[{ }^{35} \mathrm{~S}\right] \mathrm{DBT},(\mathrm{\circ})$ radioactivity due to $\left[{ }^{35} \mathrm{~S}\right] \mathrm{H}_{2} \mathrm{~S},(\Delta)$ DBT HDS conversion (adapted from Ref. 88).

Fig. 2 Mechanism of formation of a CUS on $\mathrm{MoS}_{2}$.

Fig. 3 Energy diagram of departure of a sulfur atom from $\mathrm{MoS}_{2}$ (metallic edge; adapted from Ref. 87).

Fig. 4 Arrhenius plot of the $\mathrm{H}_{2} \mathrm{~S}$ liberation reaction over $\mathrm{MoS}_{2}$ (adapted from Ref. $74 \& 88$ ) in which data of Ref. 75 have been included.

Fig. $5 S_{0}$ and $k_{\mathrm{RE}}$ as a function of the $\mathrm{Co} / \mathrm{Mo}$ ratio and the $\mathrm{Ni} / \mathrm{Mo}$ ratio $(16 \mathrm{wt} \% \mathrm{Mo}$, $260^{\circ} \mathrm{C}$ ) (from the data presented in Ref. $75,77 \& 103$ ); $S_{0}$ is the number of labile sulfur atoms and $k_{\mathrm{RE}}$ is the rate constant of $\mathrm{H}_{2} \mathrm{~S}$ release.

Fig. 6 Promotion effect of $\mathrm{Ni}$ and $\mathrm{Co}$ on the HDS and HYD performances of $\mathrm{MoS}_{2}$ based catalysts $\left(16 \mathrm{wt} \% \mathrm{Mo}, 260^{\circ} \mathrm{C}\right)$ (from the data presented in Ref. $\left.75,77 \& 103\right)$.

Fig. 7 Arrhenius plot of the $\mathrm{H}_{2} \mathrm{~S}$ liberation reaction over CoMoS as a function of the Co/Mo ratio (16 wt $\%$ Mo); results obtained over $\mathrm{Co}_{9} \mathrm{~S}_{8}\left(3.8 \mathrm{wt} \%\right.$ Co on $\mathrm{Al}_{2} \mathrm{O}_{3}$ ) are also 
reported (plotted using data presented in Ref. 75, 77\& 104).

Fig. 8 Energy diagram of departure of a sulfur atom from the CoMoS metallic edge.

Fig. 9 Energy diagram of departure of a sulfur atom from the CoMoS sulfur edge.

Fig. 10 Arrhenius plot of the $\mathrm{H}_{2} \mathrm{~S}$ liberation reaction over NiMoS as a function of the Ni/Mo ratio (16 wt\% Mo) (calculated from the data presented in Ref. $75 \& 77$ ); the point in parenthesis corresponds to a catalyst with a Ni/Mo ratio over the optimal one, i.e. with decreased performances. 
Figures

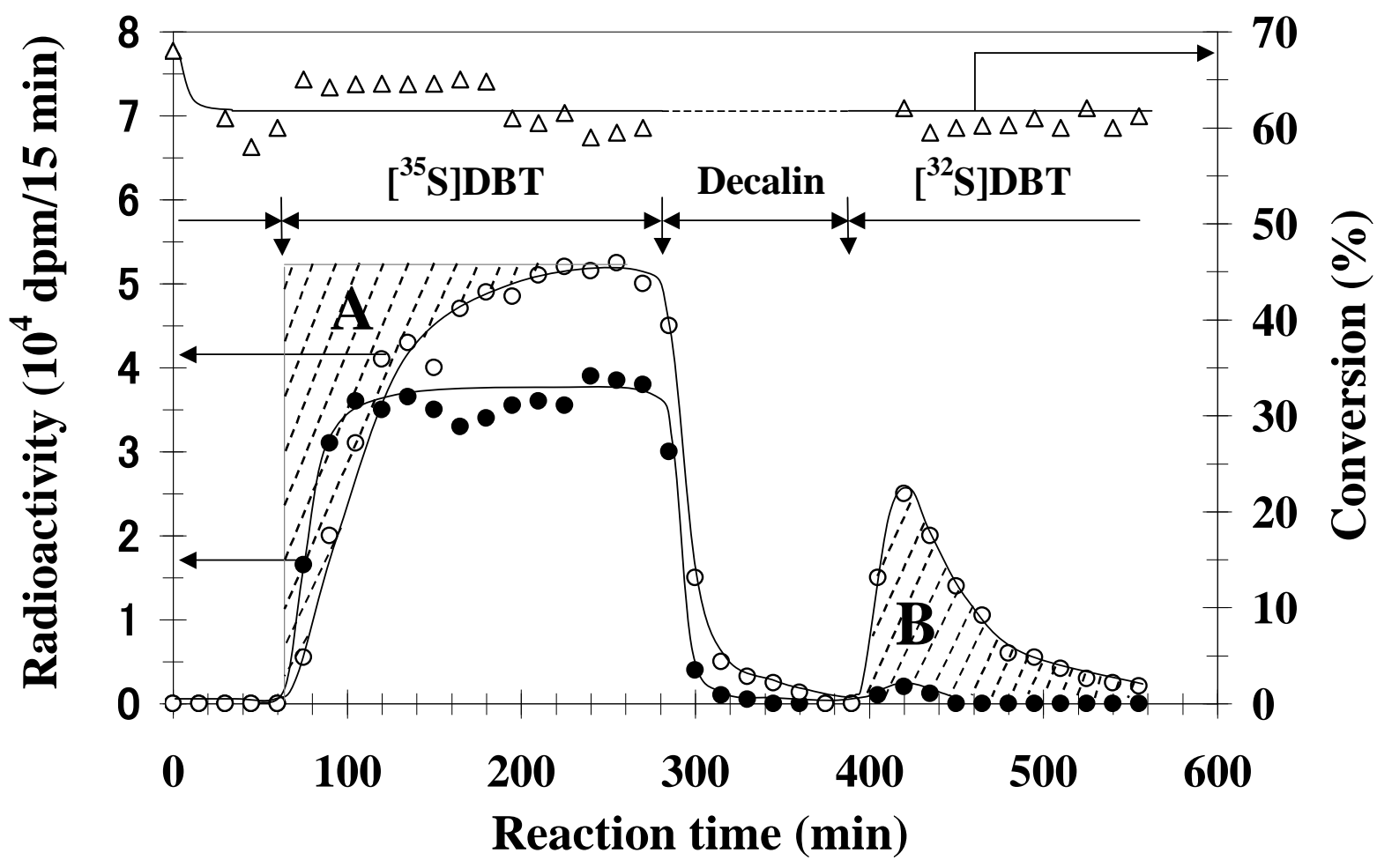

(Fig. 1)
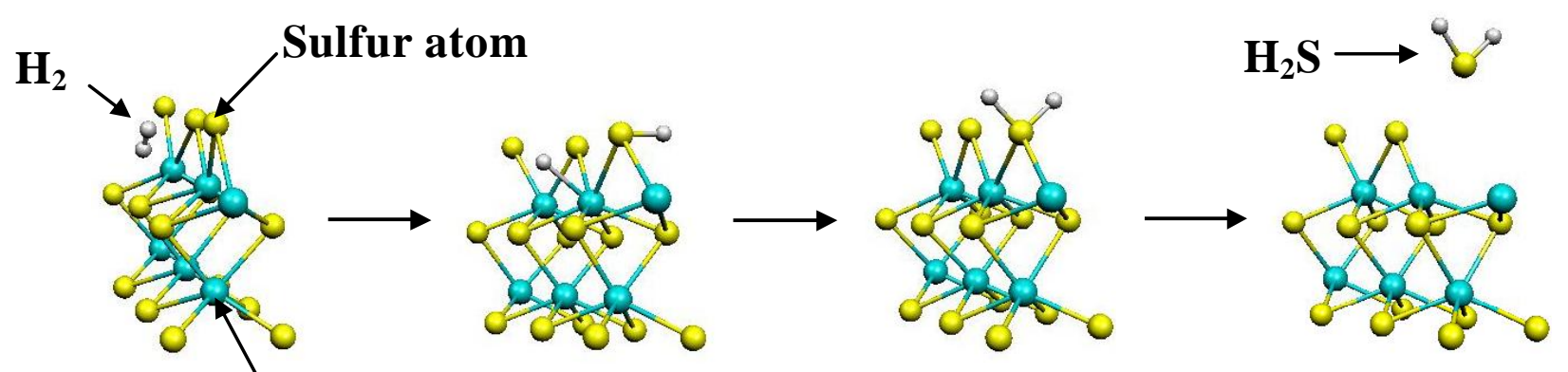

Molybdenum atom

(Fig. 2) 


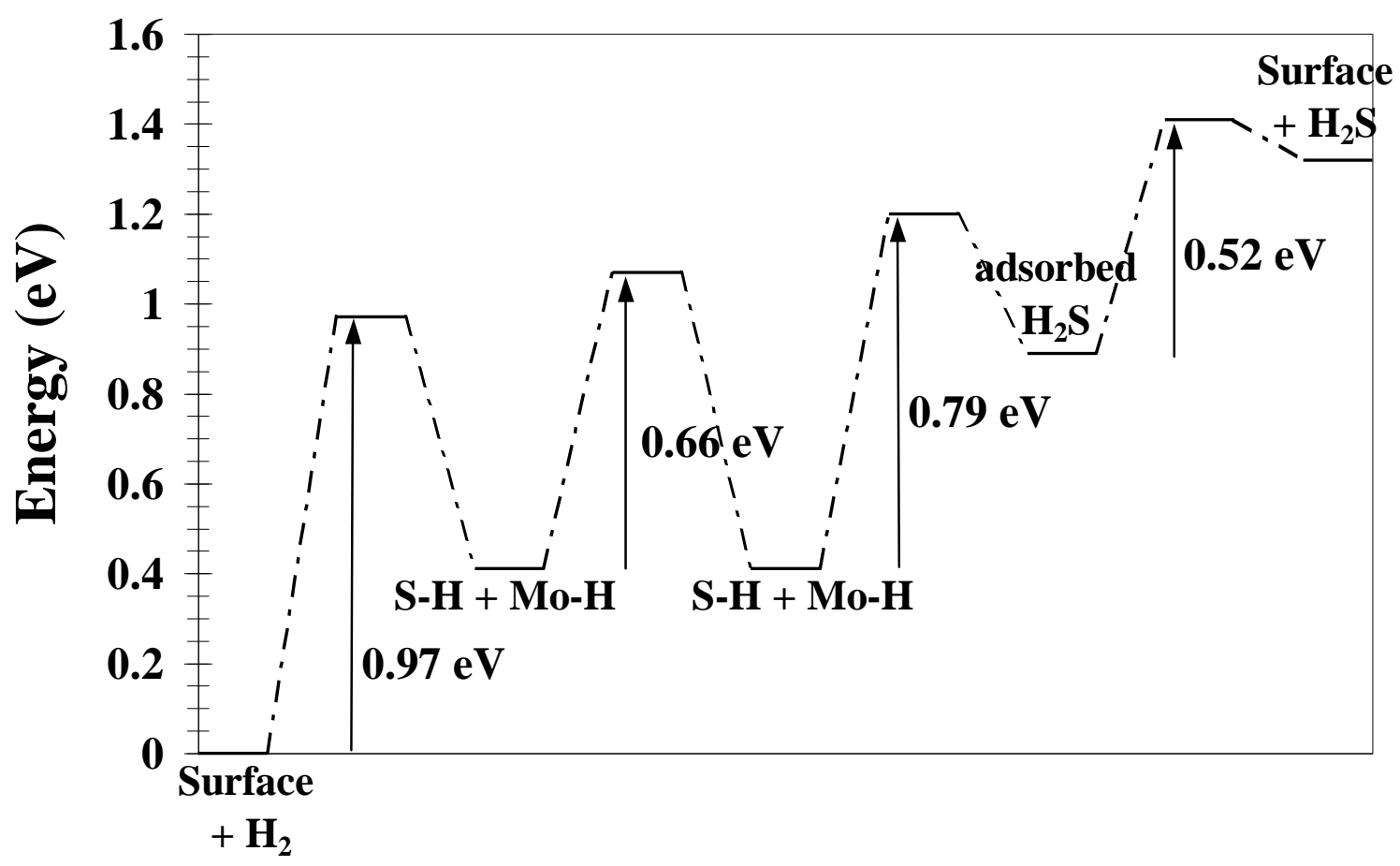

(Fig. 3)

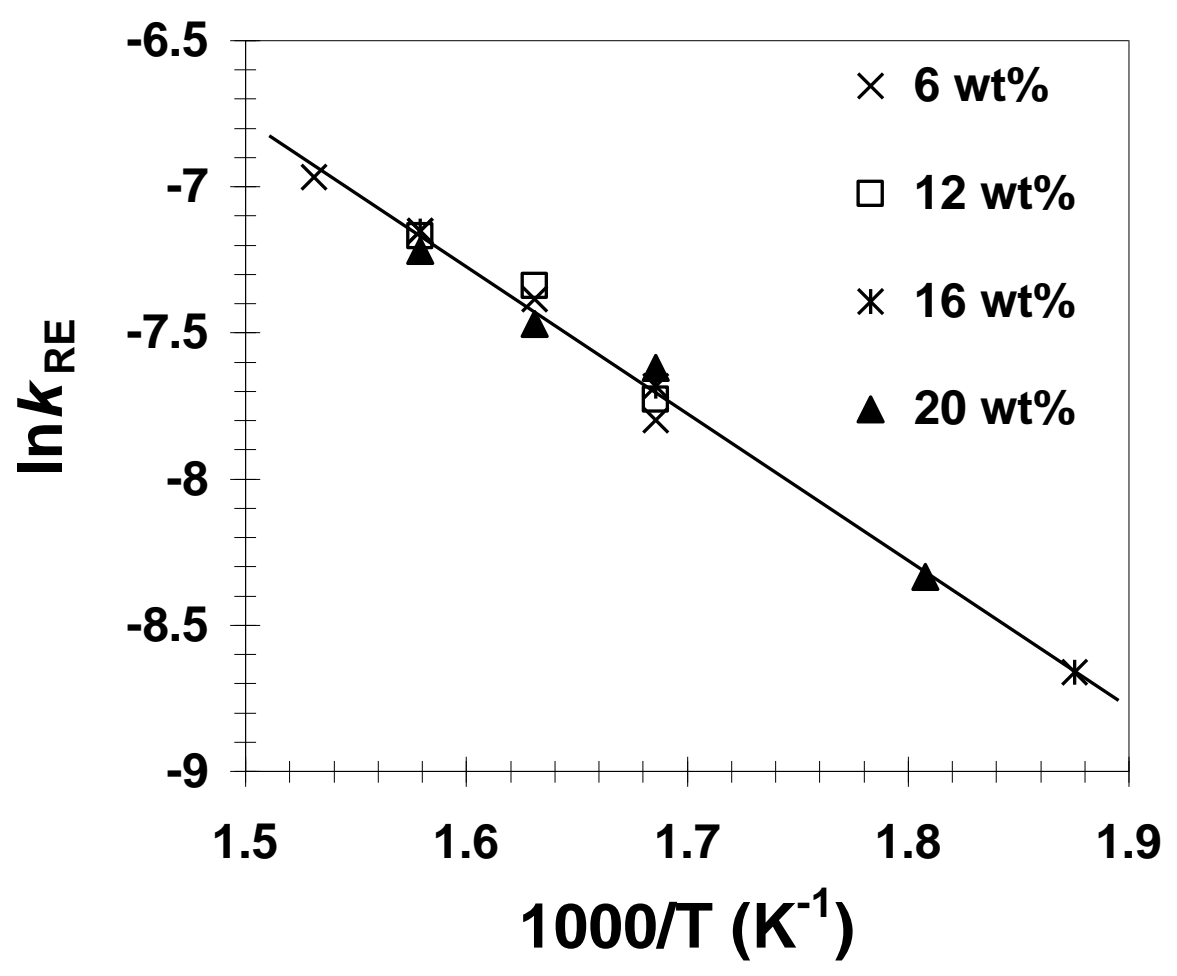

(Fig. 4) 


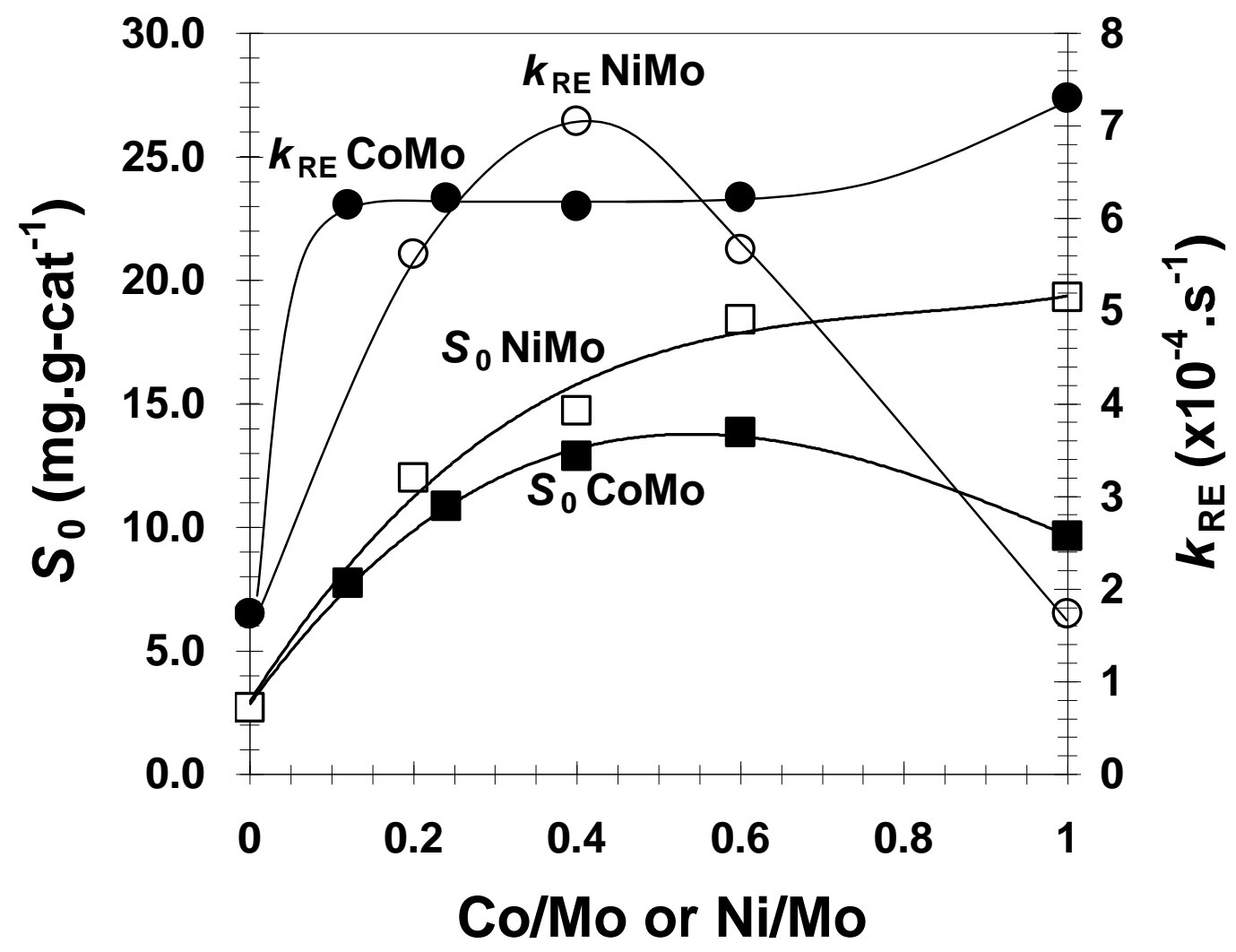

(Fig. 5)

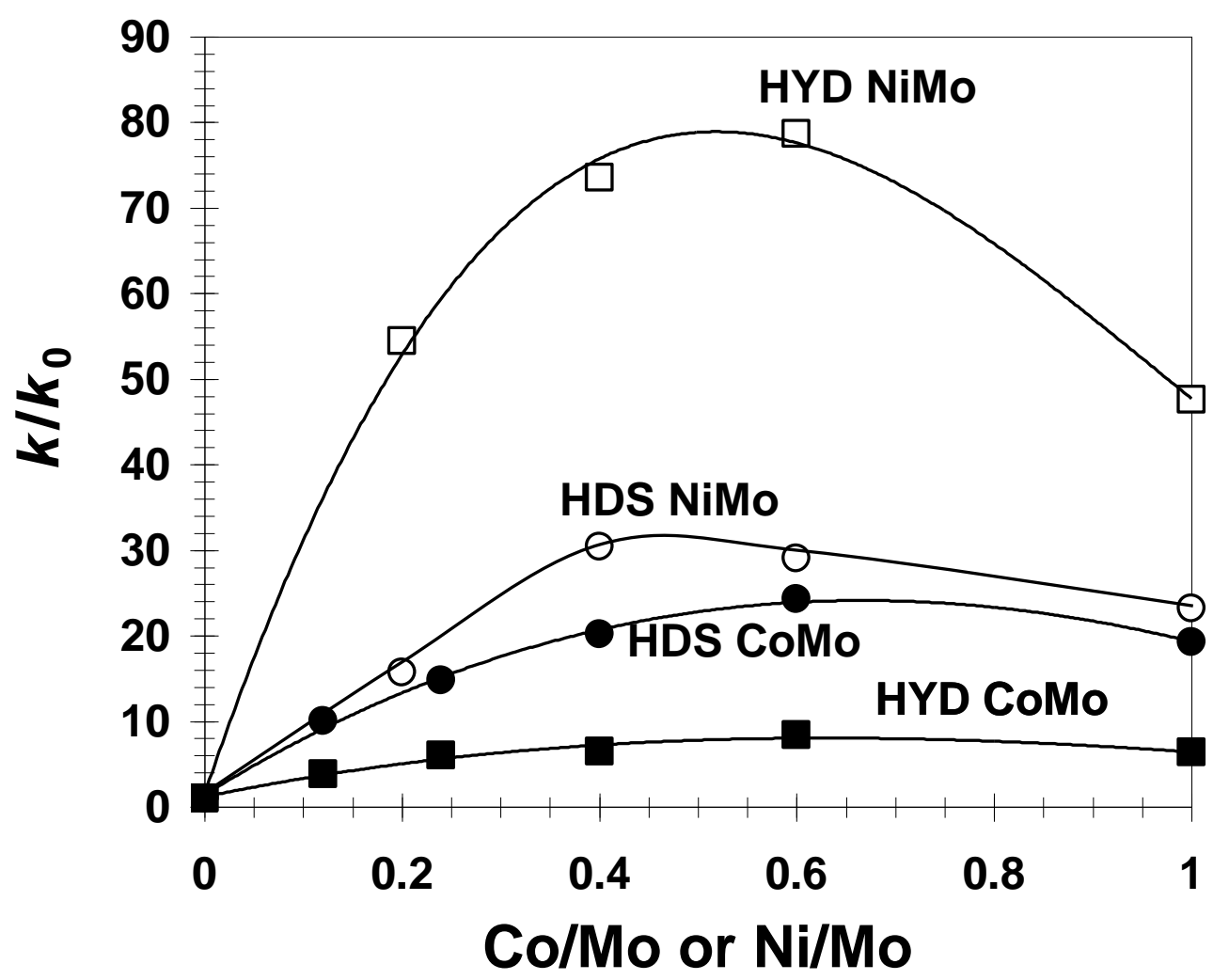

(Fig. 6) 


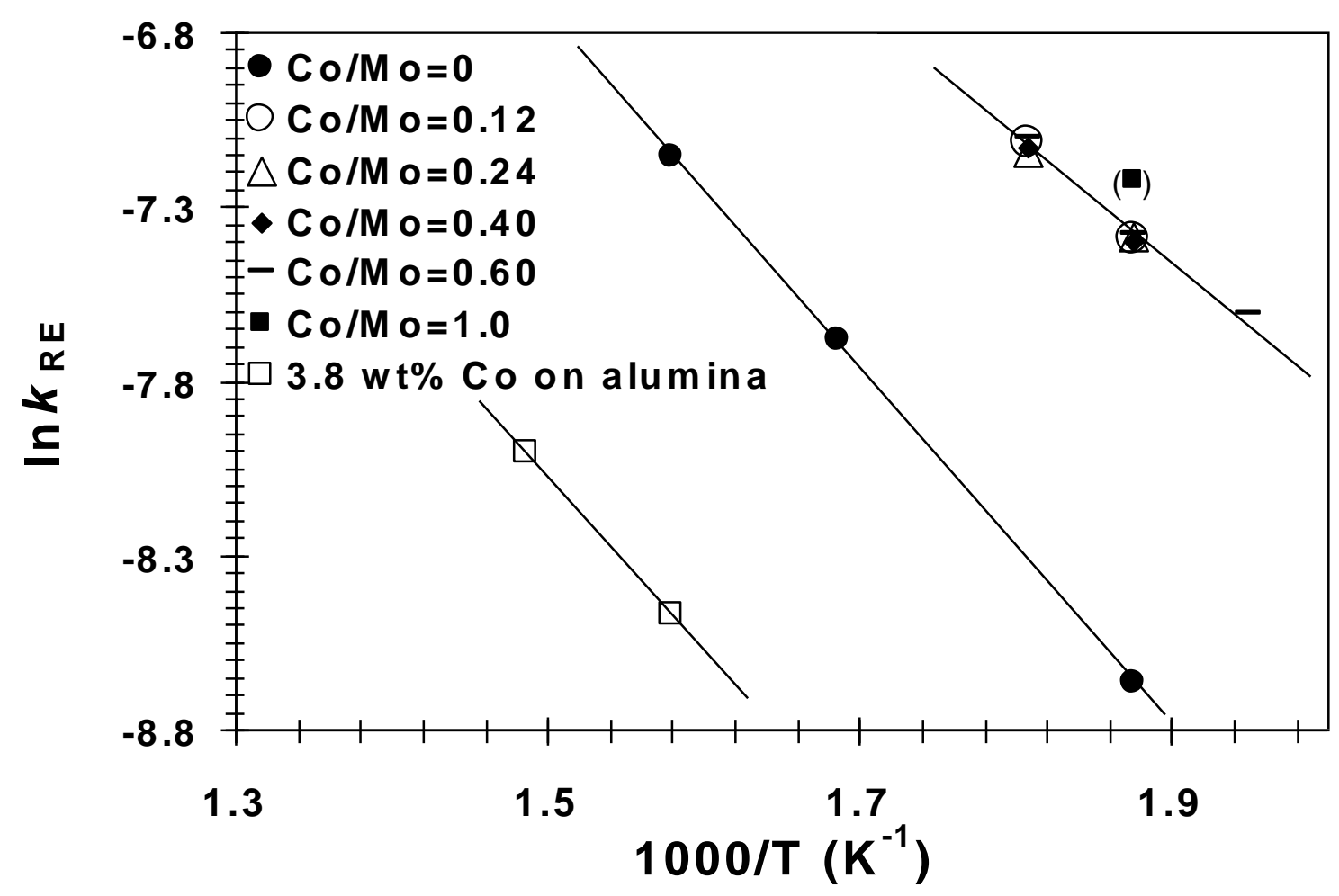

(Fig. 7)

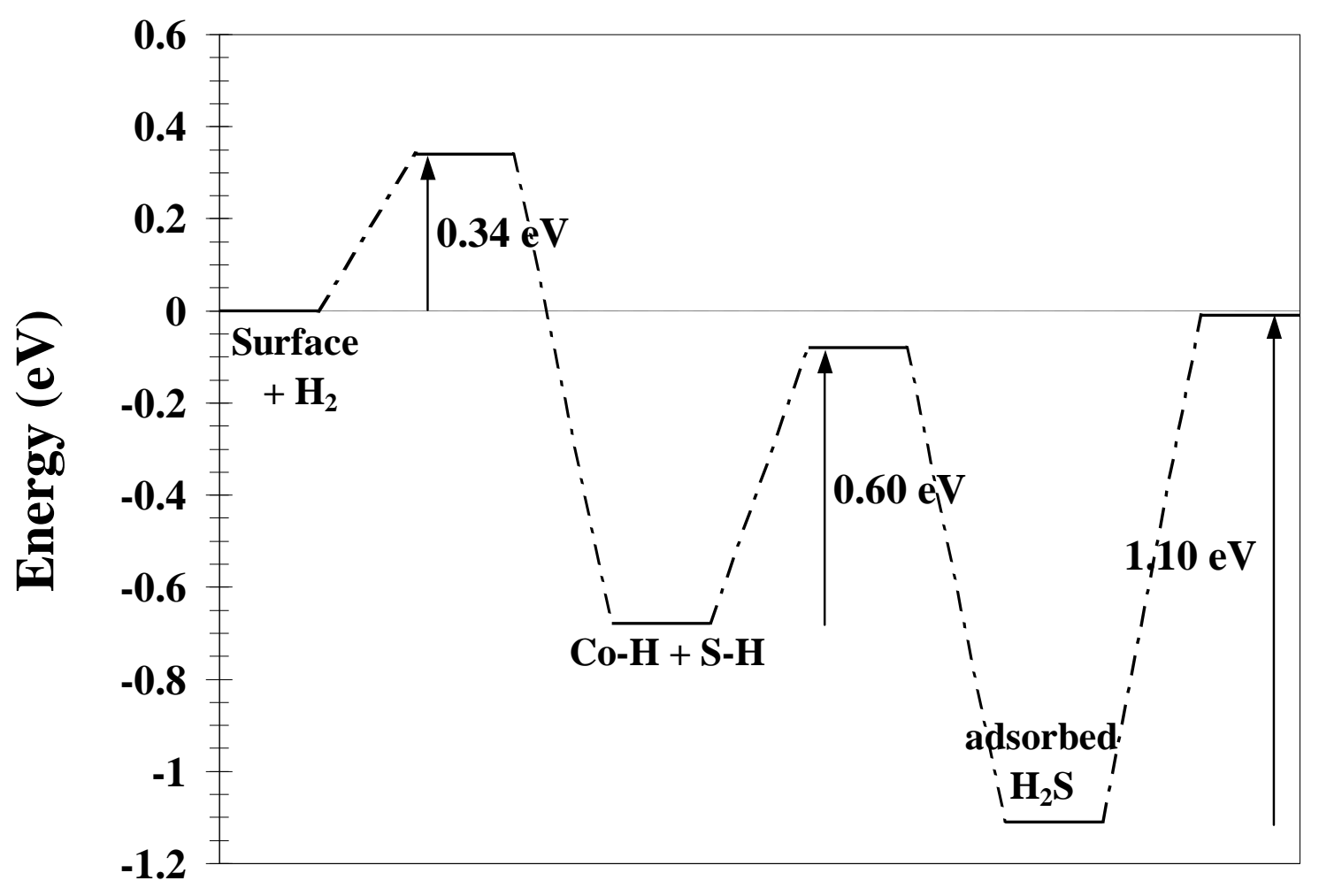

(Fig. 8) 


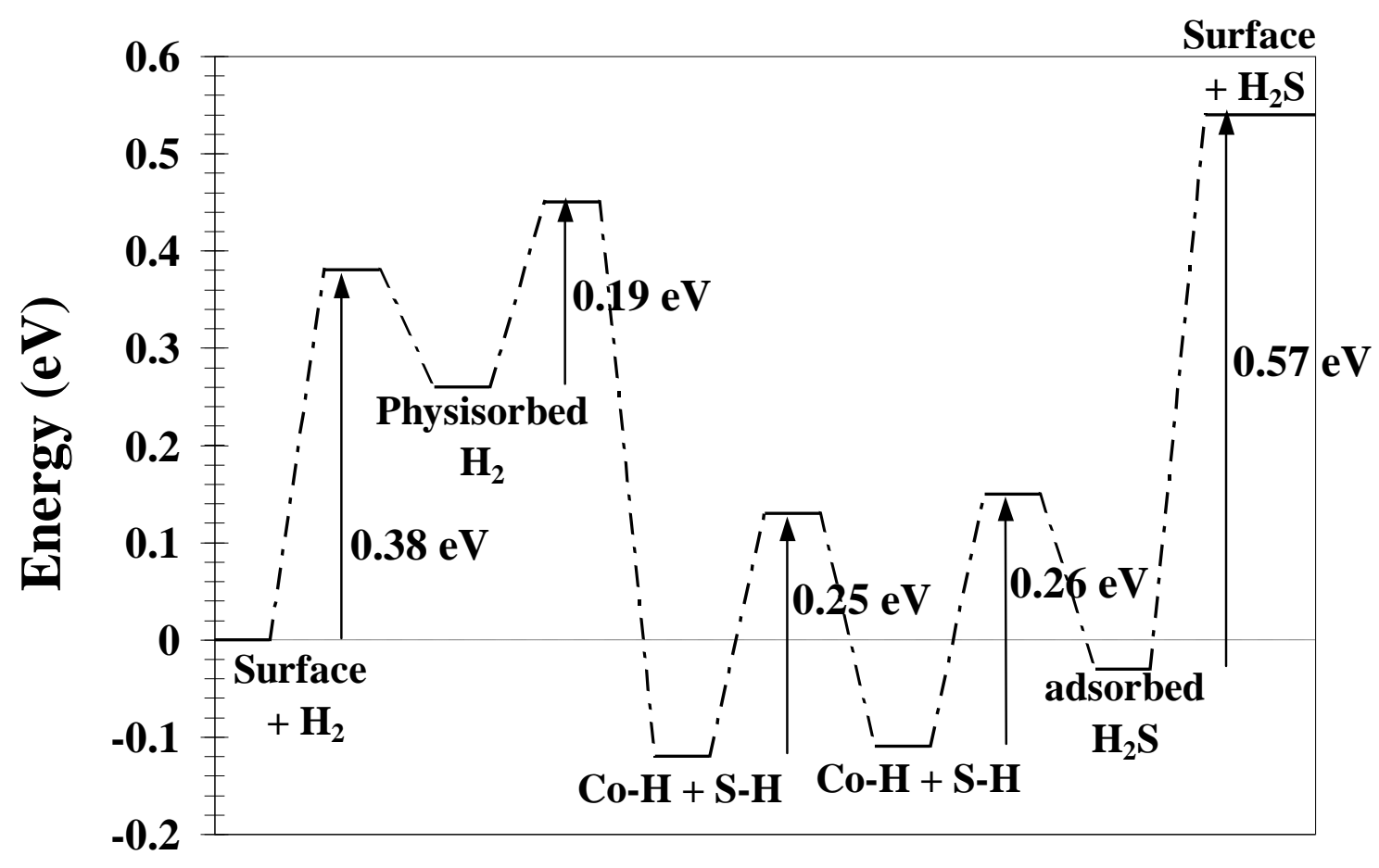

(Fig. 9)

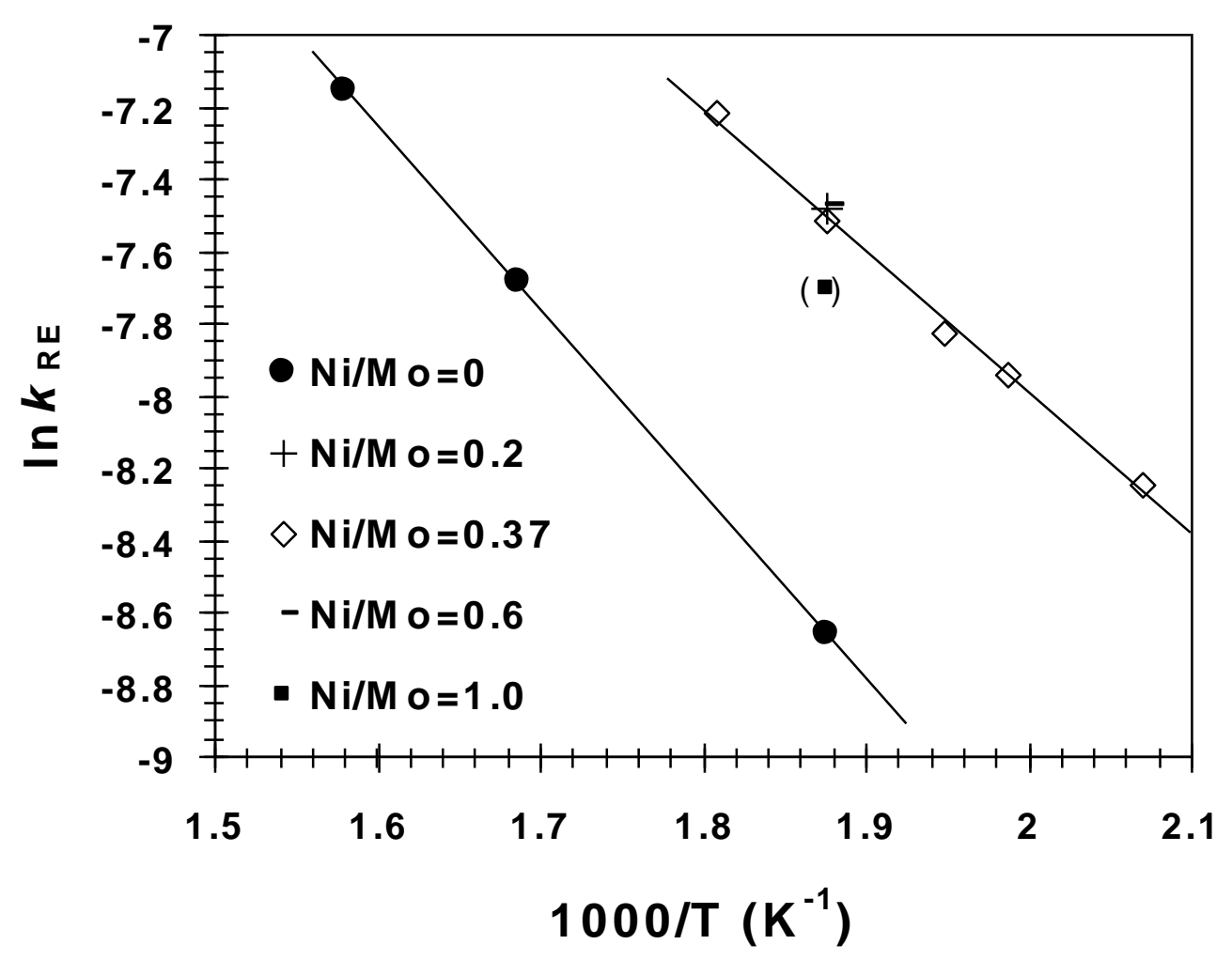

(Fig. 10) 